\title{
A Case Study Statistical evaluation of socio-economic development with a new composite index of Kashmir valley
}

\section{T.A. RAJA AND TAWHEED YOUSAF}

See end of the paper for authors' affiliations

Correspondence to : TAUHEED YOUSAF Division Agricultural Statistics, Sher-E-Kashmir, University of Agricultural Science and Technology, Shalimar, SRINAGAR (J.K.) INDIA

Email : tariqaraja@ rediffmail.com

Paper History : Received : 19.06 .2014 Accepted: 30.08 .2014
ABSTRACT : Ten districts of Kashmir valley with respect to nine development indicators were evaluated on the basis of a composite Index. The composite index on principal component analysis was employed. The level of development was obtained for agricultural, industrial and socio-infrastructural sector. Among 10 districts, the districts which stood best in agricultural sector were Anantnag and Baramulla with a combined rank of 1.5 whereas, Srinagar stood last in agricultural sector with rank of 10. In Socio-Infrastructural sector, the district standing best was Srinagar with an overall rank of 2.22 and Ganderbal with a ranking of 8.11 showed poorest performance. Similarly in industrial sector Srinagar stood best with an overall rank of 1 whereas, Ganderbal stood last in industrial sector as well with a ranking of 9.75. A compariative analysis of developmental indicators reveal that Srinagar followed by Anantnag and Baramulla are developed Pulwama, Budgam, Kupwara and Kulgam are under developed while as Shopian, Bandipora and Ganderbal are low developed. The results of the study further provide planners and policy makers to take corrective measures and improvements needed in different indicators for enhancing the level of development.

KEY WORDS : Development indicators, Composite index, Principal component analysis

HOW TO CITE THIS PAPER : Raja, T.A. and Yousaf, Tawheed (2014). Statistical evaluation of socio-economic development with a new composite index of Kashmir valley. Internat. Res. J. Agric. Eco. \& Stat., 5 (2) : 317-320. 